\title{
Effects of different legume green manures on tropical soil microbiology after corn harvest
}

\author{
Vanessa Dina Cavalcante Barros ${ }^{1}$ (D), Mario Andrade Lira Junior ${ }^{1, *}(\mathbb{D})$, Felipe José Cury Fracetto ${ }^{1}$ (D), \\ Giselle Gomes Monteiro Fracetto ${ }^{1}$ (D), Juscélia da Silva Ferreira² (D), Danilo José de Barros ${ }^{1}$ (D), \\ Adalberto Francisco da Silva Júnior ${ }^{1}$ \\ 1. Universidade Federal Rural de Pernambuco - Departamento de Agronomia - Recife (PE), Brazil. \\ 2. Universidade Federal de Pernambuco - Departamento de Energia Nuclear - Recife (PE), Brazil.
}

\begin{abstract}
Legume green manure is a popular practice for sustainable agriculture in tropical environments. The use of grain, forage and purely green manure legumes in a subhumid tropical area in Northeast Brazil was investigated to determine the total $\mathrm{C}$ and $\mathrm{N}$ contents and estimate $\mathrm{C}$-microbial biomass, soil basal respiration, microbial and metabolic quotients, before and after green manures and after the following corn. It was hypothesized that, although all legumes would increase microbial biomass and activity, there would be different effects in function of the main economic usage of the legume. The experimental design evaluated the soil before and after harvest of seven legumes: (i) purely green manures - sunn hemp (Crotalaria juncea L.) and velvet bean (Stizolobium aterrimum Piper \& Tracy); (ii) forage-Campo Grande stylo (a physical mixture of $80 \%$ of Stylosanthes captata Vog. and $20 \%$ of Stylosanthes macrocephala) and calopo (Calopogonium mucunoides Dev.) and (iii) grain - common bean (Phaseolus vulgaris L.), cowpea (Vigna unguiculata L.) and peanut (Arachis hypogaea L.), followed by corn crop. After corn harvest, soils had the same total $\mathrm{C}$ and $\mathrm{N}$ contents before legume seeding, but C-microbial biomass was significantly higher in soils with grain and purely green manures, which produced higher shoot and root dry mass. Soil basal respiration decreased after corn harvest for all legumes comparing to control treatments, but metabolic stress increased in soils with forage species. Despite this, microbial quotient indicated an efficiency of the microorganisms in degrading the residual organic matter of all green manures used in corn.
\end{abstract}

Key words: soil basal respiration, C-microbial biomass, legume residue, soil organic matter.
Received:

Jun. 5, 2020

Accepted:

Sep. 1, 2020

Section Editor:

Osvaldo Guedes Filho

*Corresponding author: mario.alirajr@ufrpe.br

\section{INTRODUCTION}

Green manure is a sustainable agronomic practice based on growing a crop, usually a legume, specifically to supply residual cover on the soil surface for subsequent crops (Diacono et al. 2019). This management has been successfully used in tropical soils due to increased organic matter incorporated and allows higher yields for corn, sugarcane and soybean, for example (Genovesi et al. 2019; Oliveira et al. 2018). Moreover, the large-scale production of green manure triggers several advantages granted to small-scale farmers for the marketable products exported as grains or fodder, which varies according to different species of precultivated legume (Oliveira et al. 2018).

Purely green manures sunn hemp (Crotalaria juncea) and velvet bean (Stizolobium aterrimum) have known use in several studies with positive yields in the development of postestablished cultures (Mabuza et al. 2016). The forages calopo (Calopogonium mucunoides) and stylo (Stylosanthes spp.) are successfully used as green manures because they have high 
fodder production in crop rotation systems (Oliveira et al. 2017; Mauad et al. 2019). On the other hand, legumes green manure based on peanut (Arachis hypogaea L.), common bean (Phaseolus vulgaris L.) and cowpea (Vigna unguiculata L.) are employed in the production and trade of its grains (Degefu et al. 2018; Nouralinezhad et al. 2018). In addition, legumes green manure is known to benefit soil chemical and microbiological attributes, mainly through biological nitrogen fixation and decomposition of plant biomass, respectively (Singh et al. 2020).

The decomposition of grain or forage legume green manure biomass favours the nutrients input into the soil (Watthier et al. 2020) and stimulates the development and performance of microorganisms, and thus the balance between storage and carbon losses (Liang et al. 2017). Together with the total soil carbon content, the abundance and microbial activity can indicate the disturbance of crop system through oxidative metabolic stress and thus its efficiency in decomposing the litter.

This study highlights the influence of legume with different economic uses as producers of grain, fodder or classics for green manure in the total $\mathrm{C}$ and $\mathrm{N}$ contents, microbial biomass carbon, basal soil respiration and in the metabolic and microbial quotients after corn-cropped, when managed according to their typical economic use. It was hypothesized that, although all legumes would increase microbial biomass and activity, there would be different effects in function of the main economic usage of the legume.

\section{MATERIAL AND METHODS}

\section{Site description and sampling strategy}

The experiment was carried out in Carpina, Pernambuco, Brazil ( $7^{\circ} 51^{\prime} 04^{\prime \prime} \mathrm{S}$ and $\left.35^{\circ} 14^{\prime} 27^{\prime \prime} \mathrm{W}\right)$ and the sampling sites have an average altitude of $180 \mathrm{~m}$, with predominant As' climate (Köppen classification system) and average annual temperature around $27^{\circ} \mathrm{C}$, and the soil is classified as abrupt dystrophic yellow argisol (Santos et al. 2018).

The experimental site was under fallow for one year, after more than a decade under sugarcane. The experiment was conducted in a randomized complete blocks design. Each plot was $4 \mathrm{~m}$ in length and $6 \mathrm{~m}$ wide, with $1 \mathrm{~m}$ between plots. The soil chemical characterization in each plot was performed according to Silva (2009) (Table 1) and soil was limed three months before the legume seeding to correct soil $\mathrm{pH}$ and raise the $\mathrm{Ca}$ and base saturation, with $2 \mathrm{t} \cdot \mathrm{ha}^{-1} \mathrm{of} \mathrm{dolomitic}$ limestone (PRNT 77\%).

Before legume seeding, glyphosate $\left(4.7 \mathrm{~L} \cdot \mathrm{ha}^{-1}\right)$ was applied, followed by plot delimitation and furrowing. The soil was fertilized according to the recommendation of Cavalcanti (2008), i.e., $173 \mathrm{~kg} \cdot \mathrm{ha}^{-1}$ of triple superphosphate and $133 \mathrm{~kg} \cdot \mathrm{ha}^{-1}$ of potassium chloride. One month after fertilization, the soil sampling for the first analyses was carried out.

The treatments were classified as: (i) grains: peanuts - Arachis hypogaea (AH), common beans - Phaseolus vulgaris (PV) and cowpea - Vigna unguiculata (VU); (ii) forage: Campo Grande stylo - a physical mix of $80 \%$ Stylosanthes capitate, 20\% Stylosanthes macrocephala (Sty) and calopo - Calopogonium mucunoides (CM); and (iii) traditionally green manure: sunn hemp - Crotalaria juncea (GMCJ) and velvet bean - Styzolobium aterrimum (GMSA) (Table 2). In addition, two control treatments with spontaneously occurring natural vegetation with predominance of Poaceae, Gramineae and Cyperaceae families (V), and soil without vegetation (C) were also evaluated.

Legume seeds were inoculated with peat inoculants before planting and three seeds were sown per pit concurrently with fertilization, without further thinning. For AH, PV and VU, a $0.25 \times 0.5 \mathrm{~m}$ spacing was adopted. For CM and Sty, the spacing was $0.5 \times 1 \mathrm{~m}$, while for GMSA and GMCJ, it was $0.5 \times 0.2 \mathrm{~m}$.

The legumes were grown for 90 days before being harvested, where the soil sampling for the second analyses was done. Corn seeds were inoculated was mixed with a liquid inoculant $\left(100 \mathrm{~mL} \cdot \mathrm{ha}^{-1}\right)$ with Azospirillum brasilense (AzzoFix) before sowing. Corn was harvested 4 months later and soil sampling was conducted for the third time.

Thus, soil sampling periods were defined as: (i) clean: soil condition before legume seeding; (ii) after legume: soil condition after legume harvest; and (iii) after corn: soil condition after corn harvest that received biomass residues of each green manure legume. 
Table 1. Soil chemical characterization before legume planting.

\begin{tabular}{|c|c|c|c|c|c|c|c|c|c|c|}
\hline $\mathbf{P}$ & pH & $\mathrm{Ca}$ & $\mathbf{M g}$ & $\mathrm{Na}$ & $K$ & Al & $\mathrm{H}$ & $S$ & CEC & v \\
\hline $\mathrm{mg} \cdot \mathrm{dm}^{-3}$ & $\mathrm{H}_{2} \mathrm{O}$ & \multicolumn{8}{|c|}{$\mathrm{cmol}_{\mathrm{c}} \cdot \mathrm{dm}^{-3}$} & $\%$ \\
\hline 7 & 5.2 & 0.9 & 0.6 & 0.06 & 0.07 & 0.7 & 7.6 & 1.6 & 10 & 16 \\
\hline
\end{tabular}

CEC: cation-exchange capacity; V: base saturation.

Table 2. Nomenclature and definitions of the green manure treatments and inoculants.

\begin{tabular}{|c|c|c|c|c|c|}
\hline Code & Cultivar & Inoculant strain & Inoculant species & $\begin{array}{l}\text { Economical } \\
\text { product }\end{array}$ & Green manure \\
\hline GMCJ & Comercial & BR 2003 & Bradyrhizobium sp. & \multirow{2}{*}{ None } & \multirow{2}{*}{ All shoot } \\
\hline GMSA & Creole & BR2811 & B. elkanii & & \\
\hline $\mathrm{CM}$ & Comercial & BR 1602 & B. japonicum & \multirow{2}{*}{$\begin{array}{c}\text { Shoot above } \\
10 \mathrm{~cm}\end{array}$} & \multirow{2}{*}{$\begin{array}{c}\text { Shoot below } \\
10 \mathrm{~cm}\end{array}$} \\
\hline Sty & Campo Grande & BR 446 & B. japonicum & & \\
\hline $\mathrm{AH}$ & BRS-HAVANA & BR 1436 & Bradyrhizobium sp. & \multirow{3}{*}{ Grain } & \multirow{3}{*}{$\begin{array}{c}\text { All shoot except for } \\
\text { grains }\end{array}$} \\
\hline PV & IPA-10 & BR 322 & Rhizobium tropici & & \\
\hline VU & IPA-207 & BR 3267 & Bradyrhizobium sp. & & \\
\hline
\end{tabular}

Inoculant strains are those currently recommended for commercial inoculant production

\section{Legume dry mass}

Sampling was performed using the quadrant method $(1 \times 1 \mathrm{~m})$ at two different points within the useful area of each plot. Ten plants were also harvested in each plot to determine the shoot, nodules and root dry mass, which were dried in drying oven at $65^{\circ} \mathrm{C}$. The shoot $\mathrm{N}$ content and accumulation were determined by the Kjeldahl method (Silva 2009).

\section{Soil total $\mathrm{C}$ and $\mathrm{N}$ contents}

The samples were collected at five random points within each plot in 0 to $10 \mathrm{~cm}$ layer, forming one composite sample per plot. The samples were stored in sterile plastic bags in a freezer with a temperature of $-20^{\circ} \mathrm{C}$.

Samplings followed exactly where the legumes were established (clean analyses) and where the legume and corn were harvested (after legume and after corn analyses). The samples were air-dried, homogenized, and sieved at $250 \mu \mathrm{m}(60 \mathrm{mesh})$ then the $\mathrm{C}$ and $\mathrm{N}$ contents were quantified by dry combustion, using elemental analyser LECO CN 2000.

\section{Microbiological attributes}

Samples were sieved at $2 \mathrm{~mm}$ to remove plant/crop and roots residues. C-microbial was obtained by the extraction-irradiation method, according to Islam and Weil (1998). Soil basal respiration was quantified according to Alef and Nannipieri (1995) and metabolic quotient was calculated according to Anderson and Domsch (1985), by the relation between basal respiration and the carbon of the microbial biomass. Microbial quotient was measured by the relationship between the C-microbial biomass and the total C.

\section{Statistical analysis}

Statistical analyses were performed using a mixed model for repeated measurements, considering the sample periods as random, and the treatment as fixed effects, at the $10 \%$ significance level, and applying Tukey's mean comparison test as appropriate.

Averages per treatment were used for linear correlation analysis, comparing each period with the subsequent ones and with legume dry masses and shoot-accumulated $\mathrm{N}$. Legume dry mass and shoot-accumulated $\mathrm{N}$ were also correlated with the after legume and after corn periods. 


\section{RESULTS}

\section{Legume dry mass}

As expected, due to their full harvest for green manure, sunn hemp and velvet bean had higher $\mathrm{N}$ shoot accumulation $\left(\sim 2.6 \mathrm{~kg} \cdot h \mathrm{ha}^{-1}\right)$, root $\left(54 \mathrm{~kg} \cdot \mathrm{ha}^{-1}\right.$ in sunn hemp and $49 \mathrm{~kg} \cdot \mathrm{ha}^{-1}$ in velvet bean) and shoot dry mass ( $559 \mathrm{~kg} \cdot \mathrm{ha}^{-1}$ in sunn hemp and $353 \mathrm{~kg} \cdot \mathrm{ha}^{-1}$ in velvet bean). However, velvet bean and calopo showed a greater nodules dry mass, reaching 161 and $378 \mathrm{~g} \cdot \mathrm{ha}^{-1}$, respectively, as shown in Table 3.

Table 3. Green manure shoot, root and nodule dry mass and accumulated N-shoot.

\begin{tabular}{cccccccccc}
\hline Measured variables & PV & VU & AH & CM & STY & GMSA & GMCJ & C & V \\
\hline SDM $\left(\mathrm{kg} \cdot \mathrm{ha}^{-1}\right)$ & $201 \mathrm{ab}$ & $175 \mathrm{~b}$ & $165 \mathrm{~b}$ & $17 \mathrm{c}$ & $8 \mathrm{c}$ & $353 \mathrm{a}$ & $559 \mathrm{a}$ & $0 \mathrm{~d}$ & $174 \mathrm{~b}$ \\
\hline RDM $\left(\mathrm{kg} \cdot \mathrm{ha}^{-1}\right)$ & $1 \mathrm{c}$ & $29 \mathrm{a}$ & $32 \mathrm{a}$ & $10 \mathrm{ab}$ & $0 \mathrm{c}$ & $49 \mathrm{a}$ & $54 \mathrm{a}$ & $0 \mathrm{~d}$ & $38 \mathrm{a}$ \\
\hline $\mathrm{NDM}\left(\mathrm{g} \cdot \mathrm{ha}^{-1}\right)$ & $2 \mathrm{c}$ & $61 \mathrm{ab}$ & $42 \mathrm{~b}$ & $378 \mathrm{a}$ & $65 \mathrm{ab}$ & $161 \mathrm{a}$ & $89 \mathrm{ab}$ & $0 \mathrm{~d}$ & $1 \mathrm{c}$ \\
\hline $\mathrm{N}$-shoot $\left(\mathrm{kg}^{\mathrm{h}} \mathrm{ha}^{-1}\right)$ & $2.3 \mathrm{ab}$ & $2.2 \mathrm{ab}$ & $2.2 \mathrm{ab}$ & $1.2 \mathrm{~b}$ & $0.9 \mathrm{~b}$ & $2.5 \mathrm{a}$ & $2.7 \mathrm{a}$ & $0 \mathrm{c}$ & $2.2 \mathrm{ab}$ \\
\hline
\end{tabular}

PV: Phaseolus vulgaris; VU: Vigna unguiculata; AH: Arachis hypogaea; CM: Calopogonium mucunoides; Sty: Stylosanthes sp.; GMSA: green manure Stizolobium aterrimum; GMCJ: green manure Crotalaria juncea; C: control treatment; V: vegetation nature; SDM: shoot dry mass; RDM: root dry mass; NDM: nodules dry mass; $\mathrm{N}$-shoot: shoot $\mathrm{N}$ accumulation. Different letters show significant differences among legume treatments by Tukey's test (10\%).

\section{Soil total $\mathrm{C}$ and $\mathrm{N}$ contents and microbiological attributes}

Soil C contents varied between 25 and $30 \mathrm{~g} \cdot \mathrm{kg}^{-1}$ and $\mathrm{N}$ contents between 1.4 and $1.7 \mathrm{~g} \cdot \mathrm{kg}^{-1}$ (Table 4) for all samplings without significant variation among treatments after corn harvest. The C:N ratio in these soils was close to 17.

Table 4. Soil total $\mathrm{C}$ and $\mathrm{N}$ contents before (clean) and after legume and corn harvest.

\begin{tabular}{|c|c|c|c|}
\hline \multirow{2}{*}{ Treatments } & \multicolumn{3}{|c|}{ After legume } \\
\hline & Clean & C contents $\left(\mathbf{g} \cdot \mathbf{k g}^{-1}\right)$ & After corn \\
\hline PV & $29 \pm 1.2$ & $28 \pm 1.2$ & $25 \pm 0.9$ \\
\hline VU & $30 \pm 1.1$ & $27 \pm 1.1$ & $25 \pm 0.8$ \\
\hline $\mathrm{AH}$ & $30 \pm 1.3$ & $27 \pm 1.1$ & $25 \pm 0.9$ \\
\hline $\mathrm{CM}$ & $28 \pm 1.2$ & $27 \pm 1.2$ & $25 \pm 1.2$ \\
\hline Sty & $29 \pm 1.1$ & $27 \pm 1.2$ & $25 \pm 1.2$ \\
\hline GMSA & $29 \pm 1.0$ & $28 \pm 0.9$ & $25 \pm 1.0$ \\
\hline GMCJ & $30 \pm 1.0$ & $29 \pm 0.9$ & $25 \pm 1.0$ \\
\hline C & $30 \pm 1.4$ & $26 \pm 0.8$ & $25 \pm 1.2$ \\
\hline \multirow[t]{2}{*}{ v } & $29 \pm 1.3$ & $25 \pm 0.7$ & $25 \pm 1.2$ \\
\hline & \multicolumn{3}{|c|}{$\mathrm{N}$ contents $\left(\mathbf{g} \cdot \mathrm{kg}^{-1}\right)$} \\
\hline PV & $1.6 \pm 0.2$ & $1.7 \pm 0.2$ & $1.4 \pm 0.1$ \\
\hline VU & $1.7 \pm 0.2$ & $1.6 \pm 0.1$ & $1.5 \pm 0.2$ \\
\hline $\mathrm{AH}$ & $1.7 \pm 0.3$ & $1.6 \pm 0.1$ & $1.4 \pm 0.3$ \\
\hline $\mathrm{CM}$ & $1.6 \pm 0.3$ & $1.6 \pm 0.1$ & $1.4 \pm 0.2$ \\
\hline Sty & $1.6 \pm 0.2$ & $1.6 \pm 0.3$ & $1.4 \pm 0.2$ \\
\hline GMSA & $1.7 \pm 0.1$ & $1.6 \pm 0.3$ & $1.4 \pm 0.1$ \\
\hline GMCJ & $1.6 \pm 0.2$ & $1.7 \pm 0.2$ & $1.5 \pm 0.3$ \\
\hline C & $1.7 \pm 0.4$ & $1.6 \pm 0.1$ & $1.4 \pm 0.2$ \\
\hline V & $1.7 \pm 0.2$ & $1.4 \pm 0.2$ & $1.5 \pm 0.2$ \\
\hline
\end{tabular}

PV: Phaseolus vulgaris; VU: Vigna unguiculata; AH: Arachis hypogaea; CM: Calopogonium mucunoides; Sty: Stylosanthes sp.; GMSA: green manure Stizolobium aterrimum; GMCJ: green manure Crotalaria juncea; C: control treatment; V: vegetation nature. 
The C-microbial was higher in the clean period, then halved or more after legume harvest. After corn harvest, this value increased again, recovering $100 \%$ of the initial value only for green manure sunn hemp and velvet bean treatments $\left(\sim 350 \mathrm{mg} \cdot \mathrm{kg}^{-1}\right)$. Similar to observed for microbial carbon biomass estimate, basal soil respiration decreased after legume harvest and then increased $100 \%$ or more after corn harvest $\left(\sim 60 \mathrm{mg} \cdot \mathrm{kg}^{-1} \cdot \mathrm{day}^{-1}\right)$, but in this case, similarly for all treatments (Table 5).

Table 5. Microbiological attributes after legume and corn harvest.

\begin{tabular}{|c|c|c|c|}
\hline \multirow{2}{*}{ Treatments } & \multicolumn{3}{|c|}{ After legume } \\
\hline & Clean & C-microbial $\left(\mathrm{mg} \cdot \mathrm{kg}^{-1}\right)$ & After corn \\
\hline PV & $463 a$ & $203 c A$ & $348 \mathrm{bA}$ \\
\hline VU & $410 a$ & $161 \mathrm{cB}$ & 291bA \\
\hline $\mathrm{AH}$ & $509 a$ & $269 \mathrm{bA}$ & $286 \mathrm{bA}$ \\
\hline $\mathrm{CM}$ & $534 a$ & $259 \mathrm{bA}$ & $232 \mathrm{bB}$ \\
\hline Sty & $464 a$ & $190 \mathrm{bB}$ & $222 \mathrm{bB}$ \\
\hline GMSA & $361 a$ & $200 \mathrm{bA}$ & $387 a A$ \\
\hline GMCJ & $386 a$ & $167 \mathrm{bB}$ & $327 a A$ \\
\hline C & $529 a$ & $183 c B$ & $329 b A$ \\
\hline V & $633 a$ & $200 \mathrm{cA}$ & $367 \mathrm{bA}$ \\
\hline \multicolumn{4}{|c|}{ Basal soil respiration $\left(\mathrm{mg} \cdot \mathrm{kg}^{-1} \cdot \mathrm{day}^{-1}\right)$} \\
\hline PV & $69 a$ & $34 \mathrm{bA}$ & $63 a B$ \\
\hline VU & $74 a$ & $37 \mathrm{bA}$ & $68 a B$ \\
\hline $\mathrm{AH}$ & $105 a$ & $33 c A$ & $58 \mathrm{bB}$ \\
\hline $\mathrm{CM}$ & $100 a$ & $34 c A$ & $65 \mathrm{bB}$ \\
\hline Sty & $99 a$ & $29 c A$ & $65 \mathrm{bB}$ \\
\hline GMSA & $85 a$ & $29 \mathrm{cA}$ & $58 \mathrm{bB}$ \\
\hline GMCJ & $106 a$ & $34 c A$ & $66 \mathrm{bB}$ \\
\hline C & $100 a$ & $31 b A$ & $82 a A$ \\
\hline V & $90 a$ & $33 \mathrm{ba}$ & $80 a A$ \\
\hline \multicolumn{4}{|c|}{ Metabolic quotient (mg.C-CO $\cdot \mathrm{g}^{-1} \mathrm{C}-\mathrm{mic} \cdot$ day $^{-1}$ ) } \\
\hline PV & $0.14 a$ & $0.16 a A$ & $0.18 \mathrm{aB}$ \\
\hline VU & $0.18 a$ & $0.23 a \mathrm{~A}$ & $0.23 \mathrm{aB}$ \\
\hline $\mathrm{AH}$ & $0.20 a$ & $0.12 \mathrm{bB}$ & $0.20 \mathrm{aB}$ \\
\hline $\mathrm{CM}$ & $0.18 \mathrm{~b}$ & $0.13 \mathrm{cB}$ & $0.28 \mathrm{aA}$ \\
\hline Sty & $0.21 b$ & $0.15 c A$ & $0.29 \mathrm{aA}$ \\
\hline GMSA & $0.23 a$ & $0.13 \mathrm{bB}$ & $0.20 \mathrm{aB}$ \\
\hline GMCJ & $0.27 a$ & $0.20 \mathrm{bA}$ & $0.20 \mathrm{bB}$ \\
\hline C & $0.18 a$ & $0.17 a A$ & $0.24 a B$ \\
\hline $\mathrm{V}$ & $0.14 b$ & $0.16 \mathrm{aA}$ & $0.21 \mathrm{aB}$ \\
\hline \multicolumn{4}{|c|}{ Microbial quotient (\%) } \\
\hline PV & $1.5 a$ & $0.7 \mathrm{bA}$ & $1.4 a \mathrm{~A}$ \\
\hline VU & $1.3 a$ & $0.6 \mathrm{bA}$ & $1.2 \mathrm{aA}$ \\
\hline $\mathrm{AH}$ & $1.6 a$ & $0.9 \mathrm{bA}$ & $1.1 \mathrm{bA}$ \\
\hline $\mathrm{CM}$ & $1.8 a$ & $0.9 \mathrm{bA}$ & $1.0 \mathrm{bA}$ \\
\hline Sty & $1.6 a$ & $0.6 \mathrm{bA}$ & $1.0 \mathrm{bA}$ \\
\hline GMSA & $1.2 a$ & $0.8 \mathrm{bA}$ & $1.2 \mathrm{aA}$ \\
\hline GMCJ & $1.3 a$ & $0.6 \mathrm{bA}$ & $1.3 a A$ \\
\hline C & $1.7 a$ & $0.6 \mathrm{bA}$ & $1.4 a \mathrm{~A}$ \\
\hline V & $2.2 a$ & $0.8 \mathrm{cA}$ & $1.5 \mathrm{bA}$ \\
\hline
\end{tabular}

PV: Phaseolus vulgaris; VU: Vigna unguiculata; AH: Arachis hypogaea; CM: Calopogonium mucunoides; Sty: Stylosanthes sp.; GMSA: green manure Stizolobium aterrimum; GMCJ: green manure Crotalaria juncea; C: control treatment; V: nature vegetation. Different lowercase and uppercase letters show significant differences among harvests for the same treatment and among treatments in the same harvest, respectively, by Tukey's test (10\%). 
The increase in the soil basal respiration led to higher metabolic quotients of all treatments after corn harvest, but only significant for treatments that received forage legumes $\mathrm{CM}$ and Sty. In spite of, the $\mathrm{C}-\mathrm{CO}_{2}$ emission after corn was significatively lower in the soils that received all legumes compared to the control treatments $\mathrm{C}$ and $\mathrm{V}$. The microbial quotient varied from 1.0 to $1.5 \%$ in all treatments, but without significant differences after the corn harvest.

\section{Data correlation}

In the clean treatment, there was a significant correlation $(\mathrm{p}<0.1)$ between nodules dry mass from legume green manure and soil total $\mathrm{C}$ and $\mathrm{N}$ contents. C-microbial and metabolic and microbial coefficients correlated negatively with shoot dry mass of legume. After corn harvest, the increase in the metabolic quotient corresponded to a decrease in the nodules, roots and shoots dry mass of each legume.

Soil total $\mathrm{C}$ contents after corn harvest correlated negatively with the microbial quotient and C-microbial in the clean period. The metabolic quotient after corn harvest also showed negative correlations with shoot $\mathrm{N}$ accumulation. $\mathrm{C}^{-\mathrm{CO}_{2}}$ emissions after corn harvest increased simultaneously with C-microbial in the clean treatment (Table 6).

Table 6. Pearson correlation coefficients and respective $p$ values between clean between legume green manure yields, and soil characterization after legume and after corn.

\begin{tabular}{cccccccc}
\hline Attributes & $\begin{array}{c}\text { C-Microbial } \\
(\text { Clean) }\end{array}$ & $\begin{array}{c}\text { qMic } \\
(\text { Clean) }\end{array}$ & $\begin{array}{c}\text { qCO } \\
(\text { Clean })\end{array}$ & SDM & NDM & RDM & N-shoot \\
\hline Total C (Clean) & NA & NA & NA & NS & -0.64 & NS & NS \\
\hline Total N (Clean) & NA & NA & NA & NS & -0.79 & NS & NS \\
\hline C-microbial (Clean) & NA & NA & NA & -0.58 & -0.1 & -0.33 & -0.44 \\
\hline$q \mathrm{CO}_{2}$ (Clean) & NA & NA & NA & -0.60 & NS & NS & NS \\
\hline$q M i c$ (Clean) & NA & NA & NA & -0.58 & -0.02 & -0.33 & -0.43 \\
\hline Total C (After legume) & -0.88 & -0.89 & 0.65 & NS & NS & NS & NS \\
\hline Total N (After legume) & -0.67 & -0.68 & NS & NS & NS & NS & NS \\
\hline Total C (After corn) & -0.88 & -0.89 & NS & NS & -0.67 & NS & NS \\
\hline$q \mathrm{CO}_{2}$ (After corn) & -0.37 & -0.39 & NS & -0.71 & -0.34 & -0.6 & -0.74 \\
\hline${\mathrm{C}-\mathrm{CO}_{2} \text { (After corn) }}$ & 0.6 & 0.6 & NS & NS & NS & NS & NS \\
\hline
\end{tabular}

Correlations based on per treatment averages $(n=9)$. Values in bold indicate significant $(p<0.1)$ correlations. C-microbial is microbial Carbon biomass estimate; $\mathrm{C}-\mathrm{CO}_{2}$ is the soil basal respiration $q \mathrm{CO}_{2}$ and $q$ Mic are metabolic and microbial quotients, respectively; SDM: shoot dry mass; RDM: root dry mass; NDM: nodules dry mass; $\mathrm{N}$-shoot, shoot $\mathrm{N}$-accumulation. NA: not applicable; NS: not significative.

\section{DISCUSSION}

Accumulated N-shoot in sunn hemp and velvet bean, both purely green manure crops, was similar to those found by Sarmento et al. (2019), who also found lettuce yields close to those obtained with mineral fertilization. This represents a considerable entry of $\mathrm{N}$ into the system, probably by biological $\mathrm{N}$ fixation (BNF). As in the studies by Kaizzi et al. (2006), velvet bean also showed greater dry mass and its allowed corn yield equivalent to that of corn receiving $40 \mathrm{~kg} \cdot \mathrm{ha}^{-1}$ of $\mathrm{N}$ as urea. In addition, the dry mass of cowpea and sunn hemp is also equivalent to that found by Ambrosano et al. (2018) in soils with organic cherry tomato production, once more showing the economic potential of these legumes used as green manure.

The shoot- $\mathrm{N}$ accumulation in all type of green manure used here was provided by the performance of diazotrophic in symbiosis with the roots of these legumes. It was evident that this symbiosis favored the nodules dry mass in calopo and common bean, since these legumes have good efficiency in generating symbiosis with native diazotrophic species (Santos et al. 2017). In addition, legume-derived $\mathrm{N}$ led to a decrease in microbial oxidative stress, as indicated by lowered metabolic quotient, after corn harvest, likely due $\mathrm{C}$ and $\mathrm{N}$ positive input and loss balance, as also seen by Hu et al. (2011). 
While superficial soil total C and N contents found after legume or corn harvest exceeded those found by Seben Junior et al. (2016) in no-tillage corn intercropped with legumes and Muchane et al. (2020) in subhumid soils under an agroforestry system, they are similar to those described by Lira Junior et al. (2020) after two years of a subhumid tropical legume-shrub-tree based silvopastoral system. This reinforces these legumes potential to contribute to the storage of $\mathrm{C}$ and $\mathrm{N}$ in these soils over time, without the need for nitrogen inputs, as also reported by Ambrosano et al. (2009) for corn growing systems with velvet bean and sunn hemp, both traditional tropical green manures.

The experiment was relatively short (i.e., less than one year) and insufficient for give a response if the green manure could increase the soil $\mathrm{C}$ and $\mathrm{N}$ total contents after the corn harvest in relation to the period before legumes seeding (clean). Even so, data from this work shows that in the absence of legumes there would be a tendency to decline in the $\mathrm{C}$ and $\mathrm{N}$ contents over time, particularly for $\mathrm{N}$ (Table 4), although not significantly so. In this sense, it was demonstrated that here there is a conservation in the soil total $\mathrm{C}$ and $\mathrm{N}$ contents.

It is known that different plant residues decompose at different rates due to contain of aromatics compounds and this can influence in C inputs in the long term (White et al. 2018). Although compounds in legume litter contain lignins and suberins, with slow decomposition (Kohmann et al. 2019), these green manures directly influenced the abundance and activity of bacteria and fungi, which are mainly responsible for the mineralization of organic matter and the supply of nutrients in the soil (Zhao et al. 2019), since the residual dry mass content of the legumes correlated negatively with the microbial oxidative stress after corn harvest.

The soil C-microbial biomass estimate declined after legume harvesting. However, the green manure made the soil capable of restoring microbial abundance (based only on C-microbial) and, hence, the values were close to those of the clean treatment, which was still under the effect of fertilization and liming. In addition, the soils that received grain legumes also have C-microbial estimates close to both control and nature vegetation treatments after the corn harvest, indicating that the residual biomass of these legumes stimulated soil microorganisms in a compensatory way, thus increasing their estimate values.

In fertilized tropical soils, the carbon microbial biomass estimate normally exceeds $500 \mathrm{mg} \cdot \mathrm{kg}^{-1}$ (Singh et al. 2020) but the estimate presented here for soils with common bean, sunn hemp and velvet bean $\left(\sim 350 \mathrm{mg} \cdot \mathrm{kg}^{-1}\right)$ after corn harvest is higher than found in tropical soils with no-tillage (Huang et al. 2020), close to that of agroforestry system soils (Beuschel et al. 2020) and superior to green manure soils with forage legumes (Bolat 2019), reinforcing the performance of these kind of legume green manure.

The microbial activity was more intense after the corn harvest than after legume harvest, but lowest than in both control and clean treatments, indicating a possible reduction on microbial activity in the soils that received all the green manures over time. Microbial litter decomposition activity during corn growth was responsible for all C- $\mathrm{CO}_{2}$ emission, but here this attribute is in decline, as this soil basal respiration estimate has not exceeded the found in pure vegetation, which normally presents less oxidative stress (Kwon et al. 2019).

Here, the soil basal respiration after corn harvest is relatively similar when compared to other treatments with inputs (Chen et al. 2020) and elevated in soils of tropical native forest (Weber et al. 2020). This high activity also led to increased metabolic quotients for all treatments after the corn harvest, which was only significant for the forage legumes calopo and stylo. This increase indicates the possibility of microbial metabolic stress in soils with these two legumes, where the losses of $\mathrm{C}$ during the decomposing microbial activity exceed the inputs of this element by organic matter, even in soils with a C:N ratio below 20 (Kohmann et al. 2019), probably due to the reduced biomass input into the system due to the short duration of the experiment, coupled with the 10-cm height economic management adopted.

The higher biomass input of sunn hemp and velvet bean might have led to greater development of fungi and actinomycetes, although this work has not examined this, since its decomposition is frequently more efficient by these microorganisms with lignin-peroxidase and manganese-peroxidase enzymes (Janusz et al. 2013). Thus, there is an increase in C-microbial estimates due to the greater proportion of their body cells and hyphae and this guarantees for fungi and actinomycetes greater representation in the soil carbon microbial biomass (Baldrian et al. 2010). Consequently, there is a decrease in the metabolic quotient in the soils that received these two typical forages legumes, particularly. On the other hand, in soils with 
forages stylo and calopo, the lower dry mass production may also have affected the C-microbial estimate and consequently increased the soil metabolic quotient.

The microbial quotient indicated that regardless of the metabolic stress observed with stylo and calopo, the microorganisms in all soils which received legume green manure degraded organic matter effectively. Thus, because there are no anthropogenic disturbances or mineral fertilization in these soils after the legume implementation, the oxidative stress in the soils of these two forages is likely due to a lower abundance of microorganisms, as was estimated by the low C-microbial, consequently.

\section{CONCLUSION}

This study evaluated seven legumes green manure and all were able to maintain the total C and $\mathrm{N}$ contents in the soil after corn harvest. Due to the higher shoot dry mass produced, the purely and grain legumes drive the higher microbial abundance in soil after corn harvest.

While forage legumes had higher metabolic stress than either grain or green manure ones, all of the green manures presented lower stresses than either control treatment, indicating increased efficiency in organic matter decomposition.

\section{ACKNOWLEDGMENTS}

All authors thank Djalma E. Simões Neto and Evanilson P Silva (UFRPE, Brazil) for their help in the field experiment.

\section{FUNDERS}

Conselho Nacional de Desenvolvimento Científico e Tecnológico

Grant Nos. 306388/2016-2, 401896/2013-7 and 483287/2013-0

Fundação de Amparo a Ciência e Tecnologia do Estado de Pernambuco

Grant Nos. APQ-0453-5.01/15, BPV-0005-5.010/18 and BPV-0008-5.01/19

Coordenação de Aperfeiçoamento de Pessoal de Nível Superior - Finance Code 001

\section{AUTHOR'S CONTRIBUTION}

Conceptualization: Lira Junior M. A. and Barros V. D. C.; Methodology: Barros V.D.C., Ferreira J. S., Barros D. J. and Silva Junior A. F.; Writing - Review and Editing: Fracetto F. J. C, Fracetto, G. G. M. and Lira Junior M. A.; Funding Acquisition: Lira Junior M. A.

\section{REFERENCES}

Alef, K. and Nannipieri, P. (1995). Methods in applied soil microbiology and biochemistry. London: Academic Press. https://doi.org/10.1016/ B978-0-12-513840-6.X5014-9

Ambrosano, E. J., Trivelin, P. C. O., Cantarella, H., Ambrosano, G. M. B., Schammass, E. A., Muraoka, T., Guirado, N. and Rossi, F. (2009). Nitrogen supply to corn from sunn hemp and velvet bean green manures. Scientia Agricola, 66, 386-394. https://doi.org/10.1590/ S0103-90162009000300014 
Ambrosano, E. J., Salgado, G. C., Otsuk, I. P., Patri, P., Henrique, C. M. and Melo, P. C. T. (2018). Organic cherry tomato yield and quality as affect by intercropping green manure. Acta Scientiarum. Agronomy, 40, e36530. https://doi.org/10.4025/actasciagron.v40i1.36530

Anderson, T.-H. and Domsch, K. H. (1985). Determination of ecophysiological maintenance carbon requirements of soil microorganisms in a dormant state. Biology and Fertility of Soils, 1, 81-89. https://doi.org/10.1007/BF00255134

Baldrian, P., Merhautová, V., Petránková, M., Cajthaml, T. and Šnajdr, J. (2010). Distribution of microbial biomass and activity of extracellular enzymes in a hardwood forest soil reflect soil moisture content. Applied Soil Ecology, 46, 177-182. https://doi.org/10.1016/j.apsoil.2010.08.013

Beuschel, R., Piepho, H.-P., Joergensen, R. G. and Wachendorf, C. (2020). Effects of converting a temperate short-rotation coppice to a silvo-arable alley cropping agroforestry system on soil quality indicators. Agroforestry Systems, 94, 389-400. https://doi.org/10.1007/ s10457-019-00407-2

Bolat, I. (2019). Microbial biomass, basal respiration and microbial indices of soil in diverse croplands in a region of northwestern Turkey (Bartın). Environmental Monitoring and Assessment, 191, 695. https://doi.org/10.1007/s10661-019-7817-1

Cavalcanti, F. J. A. (2008). Recomendações de adubação para o estado de Pernambuco: segunda aproximação. Recife: Instituto Agronômico de Pernambuco.

Chen, Q.-L., Ding, J., Zhu, D., Hu, H.-W., Delgado-Baquerizo, M., Ma, Y.-B., He, J.-Z. and Zhu, Y-G. (2020). Rare microbial taxa as the major drivers of ecosystem multifunctionality in long-term fertilized soils. Soil Biology Biochemistry, 141, 107686. https://doi.org/10.1016/j. soilbio.2019.107686

Degefu, T., Wolde-Meskel, E., Ataro, Z., Fikre, A., Amede, T. and Ojiewo, C. (2018). Groundnut (Arachis hypogaea L.) and cowpea (Vigna unguiculata L. Walp) growing in Ethiopia are nodulated by diverse rhizobia. African Journal of Microbiology Research, 12, $200-217$. https://doi.org/10.5897/AJMR2017.8756

Diacono, M., Baldivieso-Freitas, P. and Serra, F. X. S. (2019). Nitrogen utilization in a cereal-legume rotation managed with sustainable agricultural practices. Agronomy, 9, 113. https://doi.org/10.3390/agronomy9030113

Genovesi, G., Rasera, G. P., Moreski, H. M., Felipe, D. F., Costa, A. R., Andreola, R., Goncalves-Zuliani, A. M. O., Bido, G. S. and Mannigel, A. R. (2019). Parameters of soybean cultivated in succession with intercropping system of out-of-season corn with green manure. Journal of Agricultural Studies, 7, 272-281. https://doi.org/10.5296/jas.v7i4.15404

Hu, J., Lin, X., Wang, J., Dai, J., Chen, R., Zhang, J. and Wong, M. H. (2011). Microbial functional diversity, metabolic quotient and invertase activity of a sandy loam soil as affected by long-term application of organic amendment and mineral fertilizer. Journal of Soils and Sediments, 11, 271-280. https://doi.org/10.1007/s11368-010-0308-1

Huang, S., Zeng, X., Wei, Y., Bai, X., Jin, Z., Zhang, M., Wang, Z., Wang, H., Qu, J. and Di, H. (2020). Decomposition of betaine aldehyde dehydrogenase transgenic maize straw and its effects on soil microbial biomass and microbiota diversity. Applied Soil Ecology, 153, 103582. https://doi.org/10.1016/j.apsoil.2020.103582

Islam, K. R. and Weil, R. R. (1998). Microwave irradiation of soil for routine measurement of microbial biomass carbon. Biology and Fertility of Soils, 27, 408-416. https://doi.org/10.1007/s003740050451

Janusz, G., Kucharzyk, K. H., Pawlik, A., Staszczak, M. and Paszczynski, A. J. (2013). Fungal laccase, manganese peroxidase and lignin peroxidase: Gene expression and regulation. Enzyme and Microbial Technology, 52, 1-12. https://doi.org/10.1016/j.enzmictec.2012.10.003

Kaizzi, C. K., Ssali, H. and Vlek, P. L. G. (2006). Differential use and benefits of Velvet bean (Mucuna pruriens var. utilis) and N fertilizers in maize production in contrasting agro-ecological zones of E. Uganda. Agricultural Systems, 88, 44-60. https://doi.org/10.1016/j. agsy.2005.06.003 
Kohmann, M. M., Sollenberger, L. E., Dubeux Junior, J. C. B., Silveira, M. L. and Moreno, L. S. B. (2019). Legume Proportion in Grassland Litter Affects Decomposition Dynamics and Nutrient Mineralization. Agronomy Journal, 111, 1079-1089. https://doi.org/10.2134/ agronj2018.09.0603

Kwon, M. J., Natali, S. M., Pries, C. E. H, Schuur, E. A. G., Steinhof, A., Crummer, K. G., Zimov, N., Zimov, S. A., Heimann, M., Kolle, O. and Göckede, M. (2019). Drainage enhances modern soil carbon contribution but reduces old soil carbon contribution to ecosystem respiration in tundra ecosystems. Global Change Biology, 25, 1315-1325. https://doi.org/10.1111/gcb.14578

Liang, C., Schimel, J. P. and Jastrow, J. D. (2017). The importance of anabolism in microbial control over soil carbon storage. Nature Microbiology, 2, 17105. https://doi.org/10.1038/nmicrobiol.2017.105

Lira Junior, M. A., Fracetto, F. J. C., Ferreira, J. S., Silva, M. B. and Fracetto, G. G. M. (2020). Legume-based silvopastoral systems drive C and $\mathrm{N}$ soil stocks in a subhumid tropical environment. Catena, 189, 104508. https://doi.org/10.1016/j.catena.2020.104508

Mabuza, M. P., Edje, O. T. and Shongwe, G. N. (2016). Effects of inorganic fertilisers and sunnhemp (Crotalaria juncea [L.]) as a green manure crop on maize (Zea mays [L.]) growth, seed yield and labour cost. American Journal of Agriculture and Forestry, 4, 56-63. https:// doi.org/10.11648/j.ajaf.20160403.11

Mauad, M., Santana, R. S., Carli, T. H., Carli, F., Vitorino, A. C. T., Mussury, R. M. and Rech, J. (2019). Dry matter production and nutrient accumulation in Crotalaria spectabilis shoots. Journal of Plant Nutrition, 42, 615-625. https://doi.org/10.1080/0190416 7.2019 .1567779

Muchane, M. N., Sileshi, G. W., Gripenberg, S., Jonsson, M., Pumariño, L. and Barrios, E. (2020). Agroforestry boosts soil health in the humid and sub-humid tropics: A meta-analysis. Agriculture, Ecosystems and Environment, 295, 106899. https://doi.org/10.1016/j. agee.2020.106899

Nouralinezhad, A., Babazadeh, H., Amiri, E. and Sedghi, H. (2018). Effects of irrigation and nitrogen on yield and water productivity in common bean (Phaseolus vulgaris L.) and cowpea (Vigna unguiculata L.) in north of Iran. Applied Ecology and Environmental Research, 16, 3113-3129. https://doi.org/10.15666/aeer/1603_31133129

Oliveira, A. C. S., Coelho, F. C., Vieira, H. D., Crevelari, J. A., Souza, Á. I. A. F., Ferraz, T. M. and Rodrigues, A. A. C. (2017). Physiological quality and seed production of corn and Fabaceae in monoculture and intercropping. American Journal of Plant Sciences, 8, $2597-2607$. https://doi.org/10.4236/ajps.2017.811175

Oliveira, R. P., Lima, S. F., Alvarez, R. C. F., Baldani, V. L. D., Oliveira, M. P. and Brasil, M. S. (2018). Azospirillum brasilense inoculation and management of fertilizer nitrogen in maize. Brazilian Journal of Agriculture, 93, 347-361. https://doi.org/10.37856/ bja.v93i3.3246

Santos, İ. A. F. M., Lira Junior, M. A., Galdino, A. C., Fracetto, F. J. C. and Fracetto, G. G. M. (2017). New rhizobial strains for velvet bean (Stizolobium aterrimum) evaluated under greenhouse and field conditions. Ciência e Agrotecnologia, 41, 428-438. https://doi. org/10.1590/1413-70542017414012917

Santos, H. G., Jacomine, P. K. T., Anjos, L. H. C., Oliveira, V. Á., Lumbreras, J. F., Coelho, M. R., Almeida, J. A., Araujo Filho, J. C., Oliveira, J. B. and Cunha, T. J. F. (2018). Sistema Brasileiro de Classificação de Solos. Brasília: Embrapa.

Sarmento, J. J. A., Santos, J. J. F., Costa, C. C. and Bomfim, M. P. (2019). Agronomic performance of lettuce subjected to green manure with different leguminous species. Revista Brasileira de Engenharia Agrícola e Ambiental, 23, 114-118. https://doi.org/10.1590/18071929/agriambi.v23n2p114-118

Seben Junior, G. F., Corá, J. E. and Lal, R. (2016). Soil aggregation according to the dynamics of carbon and nitrogen in soil under different cropping systems. Pesquisa Agropecuária Brasileira, 51, 1652-1659. https://doi.org/10.1590/s0100-204×2016000900065

Silva, F. C. (2009). Manual de análises químicas de solos, plantas e fertilizantes. Brasília: Embrapa. 
Singh, R., Srivastava, P., Verma, P., Singh, P., Bhadouria, R., Singh, V. K., Singh, H. and Raghubanshi, A. S. (2020). Exploring soil responses to various organic amendments under dry tropical agroecosystems. In M. N. V. Prasad and M. Pietrzykowski (Eds.), Climate Change and Soil Interactions (p. 583-611). Amsterdam: Elsevier. https://doi.org/10.1016/B978-0-12-818032-7.00021-7

Watthier, M., Antonio, N. P., Gomes, J. A., Rocha, S. B. F. and Santos, R. H. S. (2020). Decomposition of green manure with different grass: legume ratios. Archives of Agronomy and Soil Science, 66, 913-924. https://doi.org/10.1080/03650340.2019.1644622

Weber, O. B., Silva, M. C. B., Silva, C. F., Sousa, J. A., Taniguch, C. A. K., Garruti, D. S. and Romero, R. E. (2020). Biological and chemical attributes of soils under forest species in Northeast Brazil. Journal of Forestry Research, 31, 1959-1973. https://doi.org/10.1007/ s11676-019-00982-1

White, K. E., Coale, F. J. and Reeves, J. B. (2018). Degradation changes in plant root cell wall structural molecules during extended decomposition of important agricultural crop and forage species. Organic Geochemistry, 115, 233-245. https://doi.org/10.1016/j. orggeochem.2017.11.004

Zhao, S., Qiu, S., Xu, X., Ciampitti, I. A., Zhang, S. and He, P. (2019). Change in straw decomposition rate and soil microbial community composition after straw addition in different long-term fertilization soils. Applied Soil Ecology, 138, 123-133. https://doi.org/10.1016/j. apsoil.2019.02.018

In the article Effects of different legume green manures on tropical soil microbiology after corn harvest with DOI: https://doi.org/10.1590/1678-4499.20200262, published in Bragantia vol.79 no.4 Campinas Oct./Dec. 2020:

In the footline where is read Bragantia, Campinas, v. 79, n. 4, p.505-515, 2020 should be read Bragantia, Campinas, v. 79, n. 4, p.630-640, 2020. 